\title{
Social and historical factors contributing to language shift among German heritage-language migrants in Australia:
}

\author{
An overview ${ }^{*}$ *
}

\author{
Jaime W. Hunt and Sacha E. Davis (Newcastle, Australia)
}

\begin{abstract}
Australia is a multicultural society in which over 300 different indigenous and migrant languages are spoken. While its cultural diversity is often celebrated, Australia's linguistic diversity is still at risk due to the inherent monolingual mindset (cf. Clyne 2005) of its population. In this paper, we use a cross-disciplinary approach, drawing on both historical and sociolinguistic sources, to investigate some of the major causes of language shift among first- and subsequent generations of post-war German-speaking migrants in Australia. While historical and societal changes have provided greater opportunities for German to be maintained as a heritage language in Australia, these developments may have come too late or have not been effective in the face of English as the dominant language in Australia and as a global language. Our investigation indicates that Australians with German as a heritage language, like many other migrant groups, are still at a high risk of shift to English, despite recent opportunities for language maintenance provided by modern society.
\end{abstract}

\section{$1 \quad$ Introduction}

The German language has had a presence in Australia since the earliest settlement of the continent by Europeans. While early German-speaking colonists tended to form enclaves or Sprachinseln, which provided appropriate conditions for language maintenance over several generations, later waves of migration settled in urban areas and under different socio-historical conditions. These conditions led to language shift becoming the norm among migrants from German-speaking lands.

We begin with a brief discussion of the use of "heritage language" and "community language" terminology in the literature on migrant languages before describing the current German-speaking population of Australia. We also outline the historical background of German speakers in

\footnotetext{
* This paper is part of a wider project on German as a Heritage Language in Newcastle and the Hunter Valley, Australia. The project explores issues concerning the history of the German-speaking community through the lens of second and third generation German-speaking migrants in the local area and investigates topics of language maintenance and shift among members of this group. We would like to express our gratitude to Dr Alyssa A. Severin at Monash University, Australia, for her comments and suggestions on an earlier version of this paper.
} 
Australia, focusing on the period from the Second World War onwards. In Section 2, we highlight the most salient factors affecting the loosely defined group of migrants with German as a common linguistic heritage. In Section 3, we review and critique some opportunities to reverse language shift and maintain German as a heritage language. We conclude in Section 4 with a prognosis of the place of the German language in Australia's multilingual and multicultural society.

\section{1 "Community language" versus "heritage language" in migrant settings}

There is little consensus within the literature on what to label the non-mainstream languages spoken by migrant groups (cf. Baldauf 2005; Clyne/Kipp 2006; Hornberger 2005; Johannessen/Salmons 2015; Kipp 2007; Pauwels 2016; Polinsky 2015; Van Deusen-Scholl 2003; Wiley 2005). Van Deusen-Scholl (2003: 218) cites a number of terms, each dominant within a different country, including "allochthonous language, home language, or language of origin" in Europe and South Africa, "immigrant minority language" in the Netherlands, and "immigrant languages" in Canada. She emphasises the significance of "recognizing that each term carries specific connotations within a specific cultural or national context or within a specific academic tradition (e.g., bilingual education vs. policy studies vs. sociolinguistics)”.

In the northern hemisphere, particularly the United States, "heritage language" appears to be the preferred term applying to the minority language(s) spoken by migrant groups. However, this term itself lacks a clear definition among scholars. Polinsky-Kagen (2007) and Polinsky (2018) condense these varying definitions into two groups: those with either a narrow or a broad focus. Preferring the narrow focus, Polinsky/Kagen (2007) and Polinsky (2018) cite Rothmann's (2009: 156) simple definition of "heritage language": "a language spoken at home or otherwise readily available to young children, and crucially this language is not a dominant language of the larger (national) society". Concentrating on the individual, not the language, they define heritage speakers as those who were "exposed to the minority language from birth" (Polinsky 2018: 4) and acquired it first before switching to the dominant language around the time of starting formal schooling. Again, they quote Rothmann (2009: 156):

$[\mathrm{A}] \mathrm{n}$ individual qualifies as a heritage speaker if and only if he or she has some command [our emphasis] of the heritage language acquired naturalistically... although it is equally expected that such competence will differ from that of native monolinguals of comparable age.

(2009: 156)

Consequently, Polinsky/Kagen (2007) and Polinsky (2018) place the individual speaker (of varying degrees of competency) at the centre of their investigations within the field of bilingualism rather than concentrating on the language itself, thus de-emphasising the importance of socio-historical factors surrounding and influencing the maintenance, use, and/or acquisition of that language.

On the other hand, Fishman's (2001c: 81) broader definition of "heritage language" emphasises the cultural, historical, and emotional connection with the speaker's linguistic past, where "a particular family relevance" is central to the maintenance, use, revitalisation, and learning and teaching of the immigrant group's language(s). His definition of "heritage language" also considers first- and subsequent generations of migrants to the United States (and by extension, other countries as well), and does not focus solely on the linguistic repertoire of the second 
generation. Further, this definition places less emphasis on the individual's exposure to the language during early childhood, because in reality, the speaker of a heritage language may have had minimal exposure, if any, to the minority language during that time. The speaker may nonetheless have such a connection to the culture of his or her parents or grandparents that creates the desire to (re)learn the language. In other words, connections to a heritage language are not necessarily determined by childhood familiarity. De Vos (1975) noted that while second generation migrants in America sought to assimilate into the Anglophone population, the third generation frequently sought the expressive emotional satisfactions of belonging to a migrant community: a sense of continuity with the past, group loyalty, and similarity of emotional experience.

In the southern hemisphere, at least in Australia and New Zealand, "community language" is the preferred term. Although there is overlap in meaning with "heritage language" in Fishman's (2001c) sense above, the two terms emphasise slightly distinct aspects. "community language" highlights the language as a living one and applies to both recent and long-established migrant groups. However, as we shall see below, the disparate origins, the qualitatively distinctive characteristics, and the geographical and social dispersal of German speakers settled in Australia mean that German speakers rarely resemble a "community". By community, we mean here a general body of people identifiable to broader society as being a distinct group living in the same place and experiencing frequent social interactions with one another. German speakers in the Australian context are more likely to be isolated from others with the same linguistic and cultural background.

In contrast to the term "community language", the term "heritage language" risks connotations of looking only into the past, detracting from modern utility and possibly excluding firstgeneration migrants. However, this idea of a heritage language because it is backward-looking - driven by family connections - is an important one. Learners and speakers seek to (re)connect with their familial past through the language of their forbearers. While the German language may form part of a vibrant and living "community" among first-generation migrants in Australia, it does not among subsequent generations. In some cases, the term "heritage language" may even assume a shift has already taken place to the mainstream language. This is indeed an important point discussed below. Heritage language and its backward-looking connotations appear to be more appropriate in the case study considered here. For these reasons, we shall use the term "heritage language" (henceforth abbreviated to HL) to emphasise the common linguistic heritage among migrants of the first or subsequent generations with ancestry in the German-speaking areas of Europe.

\subsection{Current numbers of German speakers}

Australia is a predominately English-speaking country with nearly $73 \%$ of its population of 23.4 million in 2016 speaking English only (cf. ABS 2019). However, over 300 indigenous and migrant languages are also spoken by $21 \%$ of Australians, 79,353 of whom speak German. This makes German the 13th most commonly spoken language after English today and equates to $0.3 \%$ of the overall population. (The most common languages other than English are Mandarin, Arabic, and Cantonese, spoken by $2.5 \%, 1.4 \%$, and $1.3 \%$ respectively.) 
It is difficult to calculate the exact number of German speakers in Australia over time because of a lack of consistent and reliable data collection methods. For example, as Clyne (2005) points out, only since 1976 has Australia's national Census had a question on language use. In 1976, the question asked was about the regular use of a language other than English. However, since 1986, this question has been narrowed to include the use of a language other than English only in the home and thus does not collect information about language use elsewhere. For example, second-generation migrants in exogamous relationships may speak only English at home with their spouses and children, but may speak the HL when visiting parents or relatives in Australia or while on trips abroad. This means that the figures quoted here may not be truly representative of the total number of people in Australia who actually speak German (or any other HL for that matter) outside the home. Nevertheless, in an attempt to provide an estimation of the number of German speakers in Australia, the data in Figure (1) is based on a composition of data from Clyne and Kipp (2006) and the Australian Bureau of Statistics (cf. ABS 2019). As indicated, the overall trend is a decline in not only the overall number of German speakers, but also the share of speakers in the population from approximately $1.4 \%$ in 1976 to $0.03 \%$ in 2016 . There are factors to consider such as Australia's continuous growth in population from not only natural increase but also migration from many countries, which may make these percentages appear quite small in comparison. Overall, however, the reduction in those claiming to speak German at home indicates language shift.

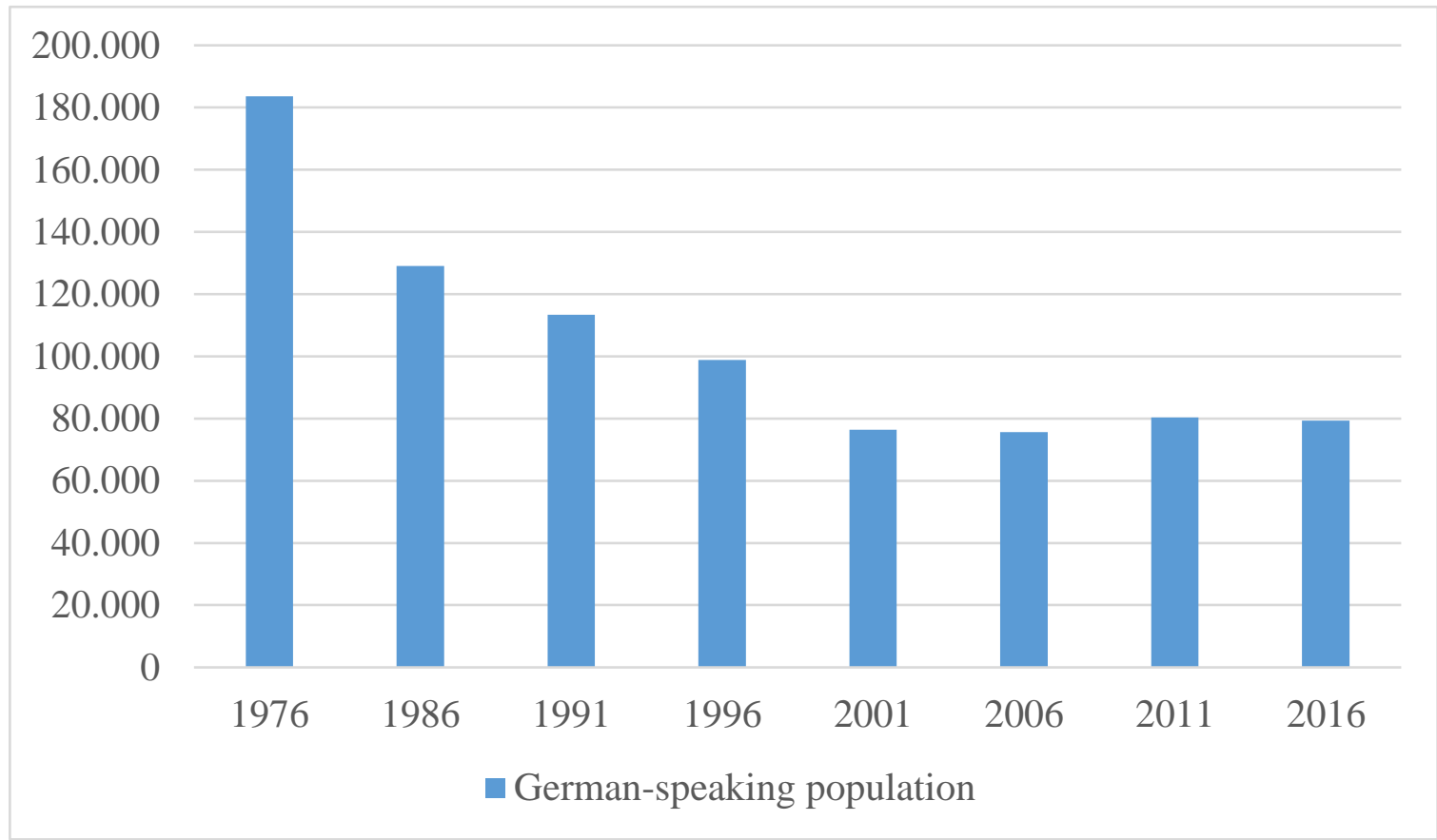

Figure 1: Number of German speakers in Australia 1976-2016, adapted from Clyne and Kipp (2006) and the Australian Bureau of Statistics (cf. ABS 2019)

In contrast to the $0.3 \%$ of the Australian population who speaks German, $4.5 \%$ claim German ancestry. This represents a considerable difference between the number of Australians who reportedly speak German and those who claim German ancestry (not to mention ancestry in other German-speaking lands). There may be several reasons for this. One reason may have to do with the narrowness of the question in the national Census relating to language use. The second, and perhaps more powerful, explanation for this schism is a high rate of language shift. 
According to Clyne and Kipp (1997), first and second-generation German speakers have the highest rate of language shift in Australia after Dutch speakers. Nearly half of German-speaking migrants shift to English, and almost all of their children speak English exclusively.

\subsection{The history of German-speaking migrants in Australia}

German speakers have played a part in Australian society since the earliest days of European colonisation. Early migration of German speakers to Australia consisted primarily of religiously motivated group settlement in rural areas such as the Barossa Valley in South Australia, the Wimmera region in Victoria, or the Riverina in New South Wales (cf. Von Heinz 2006). Similar settlement patterns are found in other countries such as in Canada and the United States (cf. Daily-O'Cain/Liebscher 2011; Johannessen/Salmons 2015; Salmons 2005). Later individual migration resulted in growing numbers of Germans in urban centres from the $1880 \mathrm{~s}$, such that by the 1950s, approximately half of those in Australia who were born in German-speaking lands were found in major cities (cf. Jupp 2001). Germans followed the same pattern of growing urbanisation throughout the new world, mostly settling in urban industrial centres where they formed a minority (cf. Bade 1992, 1995; Ness/Bellwood 2013).

German-speaking migration to Australia ceased during the First World War, and remained suppressed throughout the interwar period. From the late 1930s, however, Australia received multiple waves of migration originating from multiple points of origin throughout the Germanspeaking areas of Europe (cf. Hatoss 2006). The first wave consisted of German-speaking Jewish refugees from Germany, Austria, and East Europe, who arrived in Australia between 1938 and the late 1940s. These predominantly educated, middle class migrants settled mostly in Sydney and Melbourne and joined existing Jewish communities (cf. Rubenstein 1991; Rutland 1988). The second and largest wave, of predominantly working-class migrants, left war-torn Europe in the 1950s. This generation has assumed an iconic status as representing the German migration experience in Australia (cf. Vondra 1981). While most German citizens faced restricted entry until 1956, Australia remained open to Swiss and, from 1952, Austrians. Many migrants were also from the circa 12 million Germans from East Europe who alternately were forced to "return" to the Reich by the Nazi regime, fled advancing enemy forces in $1944 / 1945$, or were expelled by post-war governments. Facing extremely difficult housing conditions in West Germany and Austria, they still held East European citizenship, bypassing Australian migration restrictions. Thus, as in other Commonwealth states (cf. DailyO'Cain/Liebscher 2011), German migrants to Australia in the 1950s were disproportionately expellees.

Later German migration had a different character. In the 1970s and 1980s, Australia shifted its migration policies from welcoming unskilled labour to permitting residency only to skilled or wealthy migrants. Consequently, later arrivals were predominantly educated middle and upper class. The same restrictions have greatly reduced the number of migrants, although German interest in Australia remains strong. During the 1970s and 1980s, migrants were also motivated by the desire to escape the threat of nuclear war (cf. Bade 1991; Harmstorf/Cigler 1985; Tampke/Doxford 1990; Waas 1996). While occurring in distinct waves, then, post-war migration of German speakers has been predominantly individual and urban, setting the conditions for extensive language shift. 


\section{Why are German HL speakers such a high-shift group?}

The causes of language shift to the mainstream language among HL speakers can often be complex and multi-layered (see, for example, Clyne 2001; Forrest/Dandy 2018; Yagmur 2011; Zhang 2010). In this section, we begin by exploring the external societal factors affecting German-speaking migrants in Australia. We then constrain the view to the social characteristics of German-speaking migrant groups as a whole and within the group, before focusing on factors within the family and individuals that may cause language shift.

\subsection{Factors external to the group}

\subsubsection{Assimilationism}

External societal pressures acting upon migrant communities in their new country can often have a direct impact on language shift. In the political sphere in Australia, societal assimilationist ideology from around the time of WWI until the 1970s was often a driving force of language shift (cf. Winter/Pauwels 2007). While European migrants were welcomed as "New Australians", they were expected to settle amongst Anglo-Australians, avoiding the creation of ethnic enclaves. Schools were to transform migrant children, who were to speak English from the outset (cf. Jupp 2001). Authority figures such as teachers and doctors coaxed migrant parents to use only English with their children, as this would ease their cultural assimilation, as well as assisting them in to achieve their educational, social, and career goals (cf. Clyne 2005). This had a direct effect on many groups of heritage speakers who exhibited a high rate of intra- and intergenerational language shift.

\subsubsection{Anti-German sentiment}

Differentiating German heritage speakers from other migrant groups, as well as adding to the complex nature of the causes of language shift, is Germany's opposition to Australia in both World Wars. This often resulted in a negative attitude, ostracism, and sometimes hostility, towards German speakers by the broader public (cf. Hatoss 2006). Although opinion polls in the mid-1960s revealed Germans and other North Europeans to be the most popular migrants to Australia after the British (cf. Tampke/Doxford 1990), the anti-German sentiment expressed by Australian society for several decades in the $20^{\text {th }}$ century caused many German speakers to eschew their German-speaking identity. Thus, they also deliberately spoke English as a means of distancing themselves from the atrocities of the Second World War (cf. Hatoss 2006). For example, in her ethnographic study of 30 second-generation migrants, Anderson (2016) identified a strong sense of shame among her participants because of their German heritage. In addition to a more general sense of not belonging to mainstream society (common among many migrant groups), the shame that Anderson's participants expressed was particularly associated with Nazism and Second World War. Intensifying this was that half of her participants had experienced some form of prejudice during their childhood, caused by either members of the local neighbourhood or fellow classmates at school. Indeed, some participants asserted that they made conscious attempts to hide their German ancestry. Although Anderson (2016) found declining experiences of anti-German sentiment for descendants of German migrants growing up in Melbourne from the 1980s onwards, this deliberate distancing from the German heritage, 
and by extension the German language, was still evident in the late 1980s, as Pütz's (1991) study of the use of the German language among migrants in Canberra demonstrates. Pütz found that the children of German-speaking migrants deliberately shed their German identity in favour of an Australian one. Even more recently, Hatoss (2006) reports that speaking German in public is (still) not always viewed favourably. Indeed, some German-heritage speakers report being scorned in public for using German (cf. Winter/Pauwels 2007) nearly forty years after the assimilationist era had ended. As monolingual Australians rarely distinguished between German speakers of different nationality, these pressures also impacted on Austrian, Swiss and Jewish migrants (cf. Jupp 2001). This anti-German sentiment even affected speakers of other languages. For example, Nordstrom (2016) relates that one cause of the high-shift rate among Swedish speakers in Australia after the Second World War was that many feared being mistaken for being German. Deliberate language shift and acculturation would prove advantageous in such cases.

\subsection{Factors within the group}

\subsubsection{The number of new arrivals}

Language shift occurs as a result of population changes within the language group and one such change is the significant drop in the number of German-speaking migrants to Australia since the post-war wave (cf. Kipp/Clyne 2003). Figure (1) shows the spike and then decrease of migrants from the German speaking countries of Germany, Austria, and Switzerland occurring from the late 1940s. Migration from German-speaking countries appears to have steadied since the late 1990s. The number of migrants to Australia in the year 2016-2017 was 114 from Austria, 2,436 from Germany, and 218 from Switzerland (information was unavailable as to which language these migrants spoke) out of a total 162,417 new migrants settling in the country from around the world (cf. Department of Home Affairs 2019).

Gathering accurate data on the number of German speakers migrating to Australia is made difficult for several reasons. For example, the numbers of German-speaking Swiss in Figure (2) are estimated to be $63 \%$ of the overall total number of migrants from Switzerland, based on data indicating that $63 \%$ of Swiss speak German as their main language (cf. Hueber 2017). However, this estimate may be too low. According to Swiss consular figures, in 1984, 87\% of Swiss in Australia were German speaking. In 1996, 8\% were French speaking and 4\% Italian speaking (no figures were collected for Romansh) (cf. Jupp 2001). A further complicating factor is the difference between temporary and permanent migration. Not all migrants to Australia remain in the country permanently. For example, almost $44 \%$ of Swiss who migrated to Australia between 1924 and 2001 returned to Switzerland after a few years. A survey of Swiss migrants conducted in Melbourne in 1984-1985 found only 15\% planned to remain in Australia permanently (cf. Jupp 2001). Tampke and Doxford (1990) explain that many post-war migrants from Germany returned after being in Australia for some time. However, many of those who did return to Germany subsequently re-migrated to Australia permanently, returning to Germany only for holidays. 


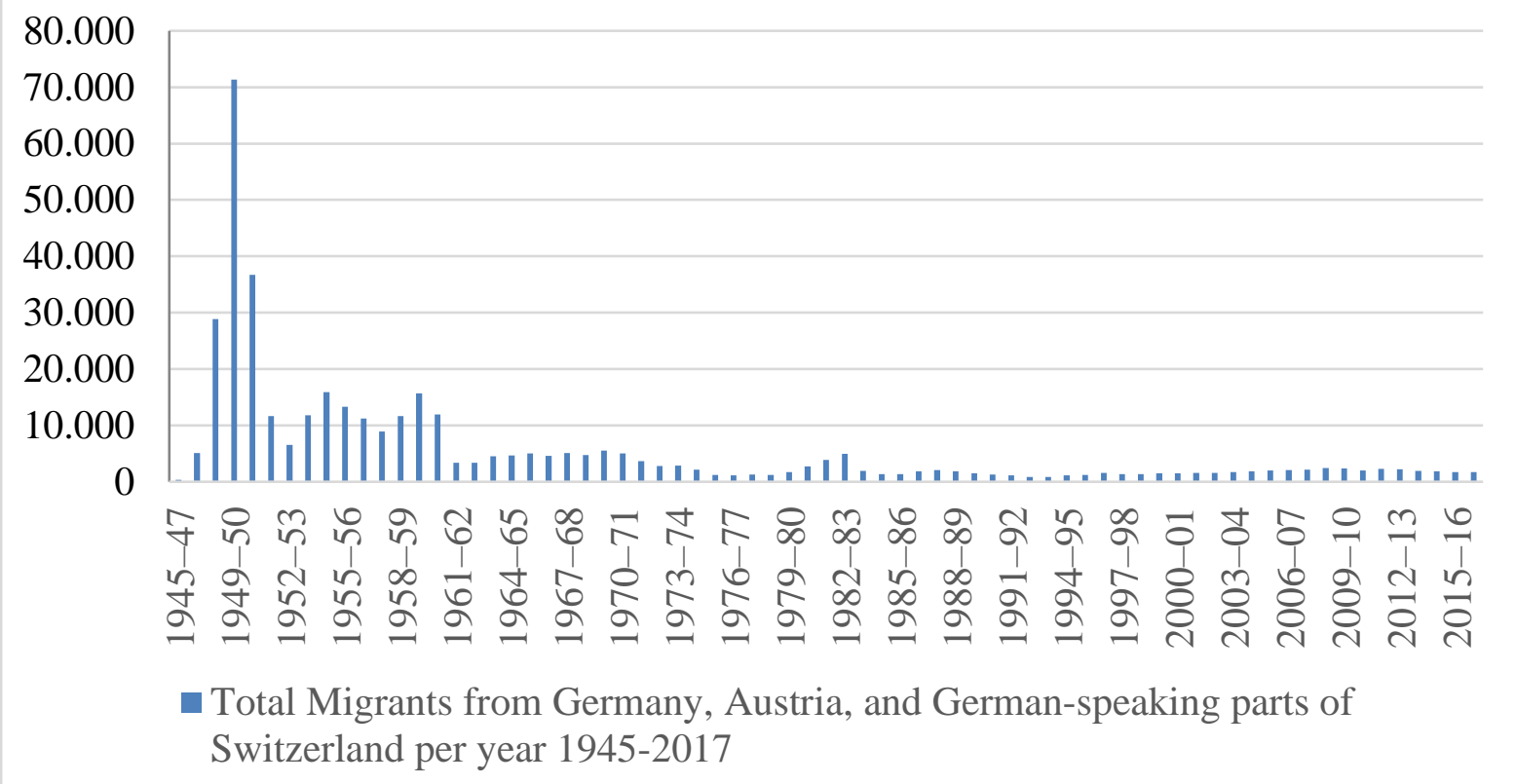

Figure 2: Total number of migrants from Germany, Austria, and German-speaking Switzerland per year 1945-2017

Because of the decline in German migration since the early 1960s, the average age of Germanborn living in Australia is relatively high. Kipp (2008) reports that nearly one-third of German speakers in Australia in 2001 were aged over 65. The combination of an aging population of German-speaking migrants and low inward migration has resulted in an overall net decline in Australian residents from German-speaking countries since 2011 (a decrease of 5\% from Germany and from Austria 9.6\%, yet an increase from Switzerland of 1.6\%). This means that there is little influx of new native speakers to maintain a buoyant German-speaking population in Australia. Historically, urban German-speaking minority populations have been dependent on inward migration in order to remain viable, as is demonstrated by the rapid decline of formerly vibrant "Germantowns" in the United States following the introduction of migration restrictions in 1923 (cf. Manz 2013; Ness/Bellwood 2013; Salmons 2005). Furthermore, while at first glance it appears that the low but steady rate of inward migration from German-speaking countries bodes well for the maintenance of German as an HL in Australia, it still does not necessarily ensure the survival of the language especially beyond the first generation. As we will investigate below, German-speaking migrants are a high-shift group and their children are particularly inclined to shift to English.

\subsubsection{Acculturation and language shift among Dutch and German-speaking migrants}

German speakers, among other northern-European migrants such as the Dutch and Scandinavians, encounter the least difficulty in acculturating to wider Anglo-Australia and shifting to English (cf. Clyne 2005; Pauwels 2016), and thus are one of the quickest migrant groups in Australia to do so (cf. Clyne 2003, 2005). This is indeed facilitated by the absence of racial distinctions between Germans and Anglo-Australians (cf. Anderson 2016). Moreover, Pauwels (2016) argues that the ease with which this acculturation occurs is because of the cultural and linguistic similarities between these groups. She claims that these similarities can indeed become an obstacle to language maintenance, especially since linguistic similarity to 
English makes it easier for speakers of German, Dutch, and Scandinavian languages to acquire and shift to English. She posits that more effort may be required to maintain these languages than it is for other languages unrelated to English, such as Mandarin or Arabic.

\subsubsection{Lack of cohesiveness}

Adding further to the already complex nature of language shift among German as an HL speakers is the weak sense of group cohesion (cf. Clyne 1988). In part, this reflects the lack of a single point of origin or "homeland" for those speakers. Another layer of complexity is added when considering the heterogeneous characteristics of the group members. These include, among others, education and social class differences between more recent migrants and established communities, high geographical dispersion, and high exogamy rates.

The first cause of there not being a clear, cohesive group identity for German-speaking migrants is that there is no single point of origin or homeland. Migrant groups more generally have highly varied local/regional origins, and may look to specific locations within (and without) the country(ies) of origin as "home" (cf. Clifford 1994; Harzig et al. 2009). German migrants are an example par excellence (cf. Maxwell/Davis 2016; O’Donnell et al. 2005; Penny 2012), being divided by the fractured history of the German states (cf. Eley 2006), strong regional particularisms (cf. Applegate 1990; Confino 2000), and waves of migration and remigration from the Twelfth Century producing substantial German communities in East Europe (cf. Maxwell/Davis 2016). This applies especially to the migrants during the post-Second World War era. These migrants remained heterogeneous within Australia (cf. Jupp 2001).

In addition to the various origins of German speakers, strong class divisions also shaped the identification of German migrants (cf. Gregoret al. 2006). While the Austrian- and GermanJewish refugees who fled Nazi rule before the War were predominantly educated, middle class migrants (cf. Jupp 2001; Rubenstein 1991; Rutland 1988), the post-war migrants were mostly working class or lower middle class background (cf. Jupp 2001; Vondra 1981). By comparison, the 1970s and 1980s saw the arrival of the Third Wave: predominantly middle-class professionals (cf. Bade 1991; Harmstorf/Cigler 1985; Tampke/Doxford 1990; Waas 1996). Regional and class divisions could reinforce each other; for example, while most Austrian refugees from Nazi rule (Jewish and otherwise) came from Vienna, much of the post-war working class Austrian migration came from the provinces and held traditional suspicions of the capital (cf. Jupp 2001; Norst/McBride 1988).

Another factor contributing to the lack of homogeneity of German-speaking migrants today as a whole is in part due to the characteristics of more recent migrants when compared to earlier arrivals. Since the 1970s, German-speaking migrants have been socially distant from the earlier post-war generation. They are better educated than their predecessors are and far more likely to have a higher degree of proficiency in English upon arrival. Indeed, as a global language, English has been the dominant foreign language learnt at school and university in Germany for quite some time (cf. Busse 2008). Recent data indicates that $86 \%$ of all school pupils in the school year of 2016-2017 were learning English, with that number rising to 95\% if elementary and special schools are excluded (cf. "Schulen Auf Einen Blick," 2018). Furthermore, English has become the medium of instruction in many tertiary education courses since the 1990s (cf. Hilgendorf 2007). The effect of such knowledge of English has an impact on language shift, as 
since many recent migrants already have a reasonable to high degree of proficiency in English, shifting to English in daily life in Australia becomes easier.

Furthermore, these recent migrants have different notions of the German-speaking lands. Unlike refugees from Nazi rule, and post-war migrants who left war-ruined Europe (cf. Grabau 2007; Vondra 1981), they are more likely to see their "home country" as prosperous and peaceful nations. These newer arrivals have come to Australia for different reasons than previous groups, and are more likely to migrate for economic reasons and to seek a better lifestyle (cf. Hatoss 2006). A consequence of these differing characteristics of education, knowledge of English, and economic status between post-war and later German-speaking migrants is that they tend not to mix with established groups, denying them a source of HL maintenance.

These regional, class and educational differences can also be seen in membership of ethnic clubs, the principle urban German language communal institutions in Australia. Where numbers permitted, Germans, Austrian, Swiss, and even Danube Swabians (Donau Schwaben) formed their own associations in Australia. However, those Austrians, Swiss and Germans from East Europe were too geographically scattered to establish their own clubs, and who were inclined to do so, joined German social clubs (cf. Harmstorf/Cigler 1985; Vondra 1981). Jewish German speakers particularly formed separate German-Jewish associations or joined broader Jewish institutions; they rarely joined (non-Jewish) German clubs (cf. Bittman 1989; Norst/McBride 1988; Vondra 1981; Wiemann 1965). Class divisions further divided membership. Before the First World War, upper and lower class Germans often maintained their own clubs in Australia, and although financial pressures forced their amalgamation in the interwar period, upper class club membership remained low (cf. Jupp 2001). The predominantly working class members of the 1950s-1970s wave of migration played a large role in revitalising pre-war German clubs, and in establishing new ones. By comparison, few later migrants joined the clubs, being alienated by their (comparatively) working class culture. Class divisions possibly also discouraged Jewish membership of German clubs. Nor were upwardly mobile second generation Germans, descended from post-war migrants, attracted to club membership. Consequently, from the 1980s German clubs and associations faced aging and declining membership (cf. Vondra 1981). Swiss clubs in Australia have experienced a similar decline due to inability to attract younger members, who frequently migrate to Australia for a short period to improve their English and gain exposure to Australian culture (cf. Jupp 2001). Overall, association membership has remained low; perhaps only a quarter of German-speakers in Australia have had any ongoing contact with or even loose ties to a club (cf. Jupp 2001).

The lack of cultural homogeneity of German-speaking migrants discussed above is exacerbated by their dispersion isolation within Australia. During the migration waves of German speakers in the 1800 s and early 1900s, most German-speaking migrants in Australia settled together in isolated rural communities where German was the language of everyday life and where a knowledge of English was not necessary. This pattern appeared not only in Australia, but also in the United States and in Canada (cf. Johannessen/Salmons 2015; Salmons 2005). These groups tended to form linguistic enclaves that were highly conducive to language maintenance over generations (cf. Pauwels 2016). While recent German-speaking migrants have settled in urban areas, they have tended not to settle within geographically concentrated community 
groups. This means that German speakers are the most widely distributed among migrant populations (cf. Kipp/Clyne 2003). For example, Pütz (1991) reports that more than $25 \%$ of participants claimed not to know of any other German speakers in their neighbourhood, meaning that the opportunities to maintain German in everyday encounters is reduced.

\subsection{Factors at the family level}

In addition to these are the causes of language shift that are also applicable to other migrant groups. These include exogamy, the presence of children in the family, the number of recent arrivals speaking the HL, and personal attitudes towards HL maintenance.

\subsubsection{Exogamy}

In contrast to the earlier, predominantly rural and religiously motivated migration of family units, migration from Germany from the late nineteenth century to the Second World War was predominantly male, resulting in a high level of mixed marriages and encouraging acculturation (cf. Borrie 1954). Post-war migration included a greater level of family migration, such that in the 1950s almost half of all migrants of German birth in Australia also had German spouses. However, individual migration has again become the norm since the 1970s, for both Germans and Austrians, such that by the 1980s approximately only $10 \%$ of migrants born in a Germanspeaking country were married to someone of the same origin (cf. Jupp 2001).

A high rate of exogamy contributes to language shift among later generations. Clyne (2003) claims that only $12.7 \%$ of second-generation Australians with Austrian heritage and $16.1 \%$ of second-generation Australians with German heritage are descended from endogamous marriages. Within this second generation, language shift is high. Indeed, Clyne and Kipp (1997) calculated the rate of language shift in the second generation in Australia by analysing the 1996 Census. They calculated the number children of endogamous marriages and compared them to children of exogamous marriages. Combining this with the question on language use in the home, they calculated a shift of $80 \%$ in the second generation if both parents were from Austria and $91.1 \%$ when only one parent was from Austria. Similarly, they showed a shift of $77.6 \%$ when both parents were from Germany, and $92 \%$ when only one parent was born in Germany.

\subsubsection{Workforce participation}

Parents' participation in the majority English-speaking workforce also encourages language shift. Schüpbach (2006) notes a clear shift to English in the Swiss-German speaking family in her case study associated with the mother taking up employment outside the family home. However, the level of language shift may depend on the type of employment. Clyne (2003) reports that language shift is less likely among unskilled labourers (especially when employed with other groups of migrants from similar backgrounds), but is more likely among skilled tradesmen. In combination with type of employment, socioeconomic status and level of education can also influence language shift. Poorer and less educated parents, that is, those more likely to work in blue-collar jobs, normally cannot access resources to help with language maintenance (cf. Schüpbach 2006; Tuominen 1999). However, the decline in the number of people employed in the manufacturing industry in Australia since the 1970s (cf. Kramer 2018) 
and the increasing education standards of German-speaking migrants, has made blue-collar work less salient a limitation to language shift in more recent decades.

\subsubsection{The presence of children in the household}

The presence of school-aged children in migrant families is another cause of language shift, indeed some studies (for example, Harres 1989) have identified children as the single largest cause of language shift in the family. Even though they may have been monolingual speakers of the HL (for example, as are those in Pütz 1991; Schüpbach 2006), once they enter school, they are strongly disposed to shifting to English and disseminating it in the home. School-aged children rarely speak the HL with their siblings (cf. Clyne 2005), and consequently may limit younger siblings' full acquisition of the HL. Pütz (1991) notes that 83\% of parents who spoke German to their children in his study received responses in English only. One cause for this could be a desire for the children to use language to challenge parental authority. This is exemplified in Schüpbach (2006), where one of the participants recalls that, as a child, he would deliberately "play games" (99) and taunt his father by ignoring him when he spoke Swiss German, who in turn would ignore him when he spoke English. Sometimes, as reported in Harres (1989), parents abandon all efforts to maintain the HL and consciously shift to English once they realise their children prefer it. Another example of this reversal occurred in a Germanspeaking family who had a child whose misbehaviour in kindergarten was due to her inability to communicate in English with her peers or caregivers. The parents decided to switch to English in the home to ease their child's linguistic assimilation outside the home.

\subsubsection{Personal attitudes}

Personal attitude towards a minority language, including how important that language is in regards to the identity of its speakers, is often cited as possibly the most important factor whether that language is maintained or lost (cf. Bradley/Bradley 2002; Wurm 2002). These values may come from within the individual or the family, or they may be influenced by broader societal factors, as mentioned earlier. The above example of language as a weapon in the power struggle between children and parents may lead to a change in attitudes and values of the parent towards the language and inhibit transmission to younger generations. Changes to parental attitudes can enhance language shift within the home because these are key to language maintenance within that domain (cf. Tuominen 1999). In situations where language maintenance is a struggle, the parent may place family cohesion above language maintenance. This is indeed what the mother in Schüpbach's (2006) study did, claiming it was "easier" to speak English to make things more relaxed in the home environment. Even without such family conflict, parents may sense a preference of their children to use English, and so switch to English to encourage family harmony (cf. Quay/Montanari 2016).

This does not necessarily mean that German-speaking parents abandon their first language completely. The reported use of German outside the home is sometimes much higher than in the home (a factor not counted in the national Census, as mentioned earlier), with $84 \%$ of L1 speakers using it with relatives and friends (cf. Winter/Pauwels 2007). In other studies, such as by Pütz (1991), only $41 \%$ of his respondents encouraged their children to speak German at home, yet $95 \%$ of them used German with their friends of their own generation. This high 
maintenance of German within the friendship domain indicates that the language values held by participants in Pütz's (1991) study may directly influence intergenerational language shift, by maintaining the language among the older generation, but failing to pass it on to the next.

\section{Opportunities for language maintenance}

\subsection{Changes in mainstream society and governmental support}

\subsubsection{Multiculturalism}

In the 1970s, a shift began in national policy away from assimilation to multiculturalism. Partly the result and partly the cause of societal change towards the acceptance of other cultures and languages in Australia, the National Policy on Languages (cf. Clyne 2005; Lo Bianco 2007) (and various iterations thereof before it) assisted in raising the status of HLs and contributed greatly towards reversing language shift within migrant communities. Among other things, this period witnessed the founding and expansion of the Special Broadcasting Service, a national radio and then also television network broadcasting in multiple languages from 1975. This provided the opportunity for members of the public to listen to locally made radio programs directly targeted towards their language group and to hear music from the homeland. SBS also contributes to language maintenance by broadcasting movies, news programs, and television shows in various languages, providing the public with further connection to their language and also increasing the awareness of languages other than English in broader society. In addition to the variety of already established locally-produced newspapers in various languages, the "golden era" of the 1970s and 1980s ushered in an increase in the number of books in various languages in local libraries (although the number of items was later reduced, according to Clyne 2001).

During the 1980s as multiculturalism was flourishing, general Australian attitudes were becoming welcoming of various nationalities (cf. Anderson 2016; Jupp 2001) and the children of post-war migrants were reaching adulthood. The Second World War was becoming more distant, anti-German sentiment had been in decline since the mid-1960s (cf. Tampke/Doxford 1990), and Australian views of West Germany in particular were increasingly positive (cf. Anderson 2016; Schulz/Soontiens 2004; Tampke/Doxford 1990). Anderson (2016) reports a decrease in the sense of shame of having a German-speaking heritage, especially among the generation born in and after that era. A flurry of publications on German history in Australia, mostly in English, and emphasising German migrants' contributions to Australian history, reflected this wider shift in community attitudes towards those of German heritage (for example, Harmstorf/Cigler 1985; Tampke/Doxford 1990; Vondra 1981).

While a sense of shame may still exist for some who have a German-speaking heritage, particularly older generations, it has been overshadowed by a sense of pride among younger generations in relation to stereotypical "German" character traits such as being punctual, efficient, and hard-working (cf. Anderson 2016). It is now socially acceptable to speak German not only in public but also to maintain it within the home. Certainly, the family home and neighbourhood are the most important environments for reversing language shift and many families make a conscious effort to maintain their language within the home (cf. Fishman 
2001b; Schüpbach 2009). Family language policy, the "explicit and overt planning in relation to language use within the home and among family members" (King/Fogle 2017: 315), may assist in reversing language shift. For example, the parents may consciously choose to speak German within the home in the attempt that their children acquire the language, something which would have been considered unthinkable by many during the assimilationist era. Many exogamous couples choose to raise their children using the "one parent, one language" principle (cf. Clyne 2003) so their children can become bilingual. Native-speaking grandparents often become involved as caregivers in families with young children where both parents work, allowing language transmission to occur (cf. Clyne 2005; Kipp 2007; Quay/Montanari 2016). Nonetheless, this may not always be successful, as discussed earlier.

\subsubsection{Educational support}

The inclusion of an educational policy within release of the Australian National Policy on Languages released in 1987 (cf. Lo Bianco 2007) ensured governmental support for the teaching of German and other HLs in schools (for details, see Clyne 2005). This provided an unprecedented boost to the maintenance of HLs in Australia because it recognised that education and literacy in an HL induces positive attitudes toward it, which is an important factor in reversing language shift (cf. Pauwels 2007; Winter/Pauwels 2007). The teaching of German in schools may also contribute to overall societal changes in attitude, enhancing the status of the language in the mainstream. Literacy in a speaker's HL encourages a positive estimation of the language itself and a higher self-esteem of heritage speakers, enhancing the status of the language overall, and contributing to language maintenance (cf. Riehl 2015). According to Riehl (2015), if a speaker with high literacy skills makes an utterance that is ungrammatical or if it deviates from the norm, he/she is more likely to be able to notice it, evaluate it, and correct/adjust it. If the speaker lacks literacy skills in the HL, he/she might not notice deviations from the grammatical norm. This then leads to the possibility of incomplete transmission in the next generation.

As positive as an educational policy with an HL focus may seem, it has not been as successful in reversing language shift as first thought. Governmental support for the teaching of HLs in schools came too late for most German heritage speakers because it was most needed in the 1950s and 1960s when the children of the post-war migration wave attended school. By the 1970s and 1980s, language shift had already become a prominent feature of the second generation. Furthermore, despite previous widespread government support for the teaching of Languages Other Than English (LOTE) in schools, funding has been greatly reduced since the 1990s leading to the reduction of teaching of languages, including German, in schools (for detailed description of this process, see Clyne 2005). According to Ellis et al. (2010), the teaching of LOTE enjoys an average of only three-quarters of an hour per week. The offering of LOTE courses is determined by financial reasons and there is little consistency in the nature of quality of instruction (cf. Lay 2016). This contributes to the current low status of LOTE education (cf. Ellis et al. 2010; Pauwels 2007), resulting in a devaluing of the HL.

Unfortunately, Australia no longer has a language policy (cf. Lanza/Curdt-Christiansen 2018) and language education appears to have all but disappeared from the political landscape as a topic of interest. Thus, the onus has returned to the communities themselves to organise their 
own language maintenance teaching programs. Many communities hold their own HL schools for children of migrants. These schools, usually held on Saturday mornings, allow children to interact with children outside the home in the HL and encourage the maintenance of the language and culture. Many such schools receive funding from state-run HL programs. However, their offering a mere few hours each week of HL instruction may not be very effective for reversing language shift either, particularly because children may be more interested in pursuing other activities instead of attending school at this time. As Schüpbach (2006) notes in her study, the children's regular attendance of the Saturday school did not prevent language shift, despite the fact that the mother was heavily involved in running the school.

Not everyone agrees that a decline in the teaching of German in schools has a negative effect on language maintenance. For example, Salmons (2005) claims that formal teaching of HLs in schools has little implication for language maintenance because they are usually taught too late, that is, only at high school or university. As discussed above, those L1 HL speakers descending from endogamous marriages may speak that language at home but switch to English during the primary school years. The teaching of HLs is, therefore, most crucial during the first few years of formal schooling while the child is still within the critical period of language acquisition. By the time this second generation reaches high school, where most foreign language education occurs, it is often too late for HL learners to acquire full native proficiency.

Nevertheless, the absence of German as an option of study prevents any possible language maintenance benefits for those who were HL German dominant in childhood. While it may not may help learners to fully acquire the language, it would provide a boost to the L1 and reinforce it at home. In a broader sense, the teaching of languages in school may add a level of prestige and vitality, enhancing the overall status of German as a language worthy of speaking and studying.

\subsection{Modern technology and more affordable international travel}

Increased ease of contact with the German-speaking lands of Europe, with the development of online technology and the increasing affordability of international travel, has provided more opportunities for language maintenance to more recent generations of migrants. Online technologies such as video calls, social networking, and mobile phone messaging appshave made it easier and cheaper for first and subsequent generation German-speakers, like all migrants, to stay in contact with family and friends in the German-speaking homelands (cf. Huang et al. 2018). These provide plenty of opportunity for not only the first generation to maintain their first language, but also later generations to interact with other German speakers in the homeland. The availability online of films, videos, music, news, comics, games, and all sorts of language learning materials also may assist in maintaining and transmitting the HL to younger generations (cf. Pauwels 2016).

In addition to this, international travel has become more affordable to more people and the opportunity for second-generation children to spend time with family and friends in the homeland in real life have become greater than before. The introduction of cheap international airfares in the 1960s made return travel much more feasible for post-war migrants (cf. Tampke/Doxford 1990). From 1966-1974, the Australian-German umbrella group Die Brücke facilitated discounted Lufthansa group flights to West Germany (cf. Grabau 2007). Since then, 
air travel has become progressively cheaper in real terms. First-generation migrants taking their children to the homeland to meet friends and relatives, perhaps spending lengthy periods of time in a language-rich environment certainly would help the younger generation to develop their language skills (cf. Pauwels 2016). In turn, these skills may be further maintained by frequent contact online after they return and/or when those relatives and friends come to Australia to visit.

While these two developments appear to be in great support in preventing or even reversing language shift among German heritage speakers, they may not be as effective as they first appear for several reasons. Firstly, the availability of a rich variety of HL resources online does not necessarily equate to their frequent use. In a study of Dutch-speaking Australians, Pauwels (2016) found that the use of online sources in Dutch was dependent on their interest in language maintenance and their proficiency to begin with (some used English almost exclusively when speaking to relatives in the Netherlands). As discussed earlier, a good deal of the population in Germany (and other German-speaking countries) is proficient in English after having learnt it for many years in school. Combined with the fact that so few second-generation migrants in Australia are proficient in German, conversations with relatives and friends are more likely to be in English. In addition, with regular visits to the homeland, German is in danger of becoming the "over there" language (Schüpbach 2006: 96), in other words, the means of communicating exclusively with family in the homeland rather than a language of everyday life in Australia. Restricting German to this domain may further contribute to language shift within the family. With little support in speaking German in Australia on a routine basis, these two means of communication (online and overseas travel) may slow, but it seems will not stop, the rate of language shift. A close-knit community, one "whose members are related to one another via bonds of kinship, affection and communality of interest and purpose", not just an online one, is most important to in reversing language shift (Fishman 2001a: 458). Indeed, Oriyama (2012) found in her study on language maintenance among second-generation Japanese speakers in Sydney, Australia, that the effect of community was more significant than language maintenance efforts of the parents and the number of homeland visits. This would indicate that heritage-language speakers have a lower chance of language maintenance if they do not participate in a community where that language is spoken. Interestingly, though, she found that two variables override effects of the community. They were the frequency of book reading and the variety of television programs watched. Therefore, even close contact with community cannot replace the maintenance effects of literacy and vocabulary enhancement gained through these.

\section{$4 \quad$ Conclusion and outlook}

Migrants to Australia with German as a heritage language who arrived around the time of the Second World War or shortly afterwards, as well as their children and grandchildren, all belong to a group of migrants particularly susceptible to language shift. During the majority of the $20^{\text {th }}$ century, Australia's assimilationist policy could be seen as the main driving force being this shift. However, since the 1970 s, the broader social and governmental factors acting upon German-speaking groups have almost reversed in favour of language maintenance. Multiculturalism, educational support of minority languages, modern technology, and travel are 
factors that can contribute to the maintenance of German as a heritage language in unprecedented ways. Nonetheless, as Clyne (2001) laments, although we have had plenty of opportunity for the maintenance of heritage languages in Australia, efforts to reverse language shift have been ineffective, particularly among German heritage speakers.

Indeed, while the external factors may have all but disappeared, the internal factors driving language shift are still significant. There are too few new migrants arriving from Germanspeaking lands to maintain the number of German speakers seen in the 1950s and 1960s. The small but constant influx of German-speaking migrants since the 1990s will assist in maintaining it as a heritage language, albeit spoken by only a small percentage of the population. Cultural and linguistic similarity with mainstream English-speaking society make language maintenance difficult, as does the lack of cohesive characteristics among speakers of German as a heritage language. Added to this, exogamy, changing workforce characteristics, the presence of Australian-born children in the family, and personal attitudes all strongly contribute to language shift. Thus, it seems that the prominent feature of Australians with a German-speaking heritage in Australia is, and will remain, language shift.

\section{References}

ABS, Australian Bureau of Statistics (2019): Census. abs.gov.au/websitedbs/ D3310114.nsf/Home/Census?OpenDocument\&ref=topBar [29.3.2019].

Anderson, Cathrin Vesna (2016): "Shame and Pride in Second-Generation German Identity in Melbourne, Australia: Emotions and White Ethnicity". Journal of Ethnic and Migration Studies, 42/9: 1439-1454. doi:10.1080/1369183X.2015.1120660.

Applegate, Celia (1990): A Nation of Provincials: The German Idea of Heimat. Berkeley, CA: University of California Press.

Bade, Klaus J. (1991): “Transatlantic Emigration and Continental Immigration: The German Experience Past and Present”. In: Bade, Klaus J. (ed.): Population, Labour and Migration in 19th- and 20th-Century Germany. New York, Berg: 135-162.

Bade, Klaus J. (1992): "German Transatlantic Migration in the Nineteenth and Twentieth Centuries”. In: Emmer, P.C./Mörner, M. (eds.): European Expansion and Migration: Essays on the Intercontinental Migration from Africa, Asia and Europe. New York, Berg: 121-156.

Bade, Klaus J. (1995): “Conclusion: Migration Past and Present: The German Experience”. In: Hoerder, Dirk/Nagler, Jörg (eds.): People in Transit: German Migrations in Comparative Perspective, 1820-1930. Cambridge, Cambridge University Press: 399-412.

Baldauf, Richard B. (2005): "Coordinating Government and Community Support for Community Language Teaching in Australia: Overview with Special Attention to New South Wales”. International Journal of Bilingual Education and Bilingualism, 8/2-3: 132-144. doi:10.1080/13670050508668602.

Bittman, Karl (1989): “The Viennese Theatre - a Retrospective View”. Australian Jewish Historical Society Journal, 10/5: 408-419.

Borrie, W. D. (1954): Italians and Germans in Australia : A Study of Assimilation. Melbourne: Australian National University.

Bradley, David/Bradley, Maya (2002): Language Endangerment and Language Maintenance: An Active Approach. London, UK: Routledge. 
Busse, Ulrich (2008): „Anglizismen im Deutschen: Entwicklung, Zahlen, Einstellungen“. In: Moraldo, Sandro M. (ed.): Sprachkontakt Und Mehrsprachigkeit: Zur Anglizismen in Deutschland, Österreich, Der Schweiz und Italien. Heidelberg, Winter: 37-68.

Clifford, James (1994): “Diasporas”. Cultural Anthropology, 9/3: 302-338.

Clyne, Michael (1988): "The German-Australian Speech Community: Ethnic Core Values and Language Maintenance". International Journal of the Sociology of Language, 1988/72: 67. doi:10.1515/ijsl.1988.72.67.

Clyne, Michael (2001): “Can the Shift from Immigrant Languages Be Reversed in Australia?". In: Fishman, Joshua A. (ed.): Can Threatened Languages Be Saved? Reversing Language Shift, Revisited: A 21st Century Perspective. Bristol, UK, Channel View Publications: 364-390.

Clyne, Michael (2003): Dynamics of Language Contact: English and Immigrant Languages. Cambridge, UK: Cambridge University Press.

Clyne, Michael (2005): Australia's Language Potential. Sydney, NSW: University of New South Wales Press.

Clyne, Michael/Kipp, Sandra (1997): "Trends and Changes in Home Language Use and Shift in Australia, 1986-1996". Journal of Multilingual and Multicultural Development, 18/6: 451-473. doi:10.1080/01434639708666334.

Clyne, Michael/Kipp, Sandra (2006): “Australia's Community Languages”. International Journal of the Sociology of Language, 2006/180: 7-21. doi:10.1515/IJSL.2006.037.

Confino, Alon (2000): The Nation as a Local Metaphor: Wurttemberg, Imperial Germany, and National Memory, 1871-1918. Chapel Hill: University of North Carolina Press.

Daily-O'Cain, Jennifer/ Liebscher, Grit (2011): “Germans from Different Places: Constructing a German Space in Urban Canada". Journal of Germanic Linguistics, 23/4: 315-345. doi:10.1017/S1470542711000183.

De Vos, George. A. (1975): "Ethnic Pluralism: Conflict and Accommodation. Ethnic Identity: Cultural Continuities and Change. In: De Vos, George A./Romanucci-Ross, Lola (eds.): Palo Alto, CA: Mayfield Publishing Company: 5-41.

Department of Home Affairs (2019): Historical Migration Statistics. https:/data.gov.au/data/dataset/historical-migration-statistics/resource/8aa8ef88-84184b65-ad48-48cad7f7e58b [24.4. 2019].

Eley, Geoff (2006): "How and Where is German History Centred?". In: Gregor, Neil et al. (eds.): German History from the Margins. Bloomington, IN: Indiana University Press: 268286.

Ellis, Elizabeth et al. (2010): "The Janus Face of Monolingualism: A Comparison of German and Australian Language Education Policies". Current Issues in Language Planning, 11/4: 439-460. doi:10.1080/14664208.2010.550544.

Fishman, Joshua A. (2001a): "From Theory to Practice (and Vice Versa): Review, Reconsideration and Reiteration”. In: Fishman, Joshua A. (ed.): Can Threatened Languages Be Saved? Reversing Language Shift, Revisited: A 21st Century Perspective. Bristol, UK, Channel View Publications: 451-483.

Fishman, Joshua A. (2001b): "Why is it so Hard to Save a Threatened Language?". In: Fishman, Joshua A. (ed.): Can Threatened Languages Be Saved? Reversing Language Shift, Revisited: A 21st Century Perspective. Bristol, UK, Channel View Publications: 1-22. 
Fishman, Joshua A. (2001c): "300-plus Years of Heritage Language Education in the United States". In: Peyton, Joy Kreeft et al. (eds.): "heritage language"s in America: Preserving a National Resource. Washington, DC: Delta Systems and Center for Applied Linguistics: 91-98.

Forrest, James/Dandy, Justine (2018): "Proficiency in English, Linguistic Shift and Ethnic Capital: An Intergenerational Analysis of Non-English Speaking Background Immigrant Groups in Sydney, Australia”. Journal of Multilingual and Multicultural Development, 39/2: 111-123.

Grabau, Willi (2007): The First 50 Years 1957 - 2007: A History of the Germania Club Newcastle. Warners Bay, NSW: Germania Club Newcastle.

Gregor, Neil et al. (eds.) (2006): German History from the Margins. Bloomington, IN: Indiana University Press.

Harmstorf, Ian/Cigler, Michael (1985): The Germans in Australia. Melbourne AE Press.

Harres, Annette (1989): “'Being a Good German’: A Case Study Analysis of Language Retention and Loss among German Migrants in North Queensland". Journal of Multilingual and Multicultural Development, 10/5: 383-399. doi:10.1080/01434632.1989.9994385.

Harzig, Christiane et al. (2009): What Is Migration History? Cambridge: Polity Press.

Hatoss, Anikó (2006): "Language, Acculturation and Identity in the German Community of Rural South East Queensland”. Language Awareness, 15/2: 80-96. doi:10.1080/09658410608668852.

Hilgendorf, Suzanne K. (2007): "English in Germany: Contact, Spread and Attitudes". World Englishes, 26/2: 131-148.

Hornberger, Nancy H. (2005): "Heritage/Community Language Education: US and Australian Perspectives". International Journal of Bilingual Education and Bilingualism, 8/2-3: 101-108. doi:10.1080/13670050508668599.

Huang, Wei-Jue et al. (2018): "Attachment to the Home Country or Hometown? Examining Diaspora Tourism across Migrant Generations". Tourism Management, 68: 52-65.

Hueber, Sebastian (2017): Language - Facts and Figures. www.eda.admin.ch/aboutswitzerland/en/home/gesellschaft/sprachen/die-sprachen---fakten-und-zahlen.html [27.11.2017].

Johannessen, Janne Bondi/Salmons, Joseph C. (2015): Germanic "heritage language"s in North America: Benjamins.

Jupp, James (ed.) (2001): The Australian People: An Encyclopedia of the Nation, its People and Their Origins. Cmbridge: Cambridge University Press.

King, Kendall A/Fogle, Lyn Wright (2017): "Family Language Policy". In: McCarty, Teresa L./May, Stephen (eds.): Language Policy and Political Issues in Education. Cham, Springer International Publishing: 315-327.

Kipp, Sandra (2007): “Community Languages and the 2001 Australian Census”. In: Pauwels, Anne et al. (eds.): Maintaining Minority Languages in Transnational Contexts. Basingstoke, Hampshire, Palgrave MacMillan: 13-29.

Kipp, Sandra (2008): "Migration, Language Use, and Identity: German in Melbourne, Australia, since World War II". In: Schulze, M. et al. (eds.): German Diasporic Experiences: Identity, Migration, and Loss. Waterloo, Ontario, Wilfried Laurier University Press.

Kipp, Sandra/Clyne, Michael (2003): "Trends in the Shift from Community Languages : Insights from the 2001 Census". People and Place, 11/1: 33-41. 
Kramer, Ted (2018): "Manufacturing and Structural Change in the Australian Economy". Ecodate, 32/2: 8-12.

Lanza, Elizabeth/Curdt-Christiansen, Xiao Lan (2018): "Multilingual Families: Aspirations and Challenges". International Journal of Multilingualism, 15/3: 231-232. doi:10.1080/14790718.2018.1477091.

Lay, Tristan (2016): „Die deutsche Sprache in Australien: Eine aktuelle Bestandsaufnahme“. Jahrbuch für Internationale Germanistik, 47/2: 85-108. doi:10.3726/82052_85.

Lo Bianco, Joseph (2007): "Contrasting and Comparing Minority Language Policy: Europe and Australia". In: Pauwels, Anne et al. (eds.): Maintaining Minority Languages in Transnational Contexts. Basingstoke etc.: MacMillan: 78-106.

Manz, Stefan (2013): Constructing a German Diaspora: The “Greater German Empire”, 1871 1918. Oxford: Routledge Taylor \& Francis Group.

Maxwell, Alexander/Davis, Sacha E. (2016): “Germanness Beyond Germany: Collective Identity in German Diaspora Communities”. German Studies Review, 39/1: 1-15.

Ness, Immanuel/Bellwood, Peter (eds.) (2013): The Encyclopedia of Global Human Migration. Oxford: Wiley-Blackwell.

Nordstrom, Janica (2016): "Parents' Reasons for Community Language Schools: Insight from a High-Shift, Non-Visible, Middle-Class Community". Language and Education, 30/6: 519-535. doi:10.1080/09500782.2016.1168431.

Norst, Marlene J./McBride, Johanna (1988): Austrians and Australia. Potts Point, NSW: Athena Press Sydney.

O'Donnell, Krista et al. (eds.) (2005): The Heimat Abroad: The Boundaries of Germanness. Ann Arbor: University of Michigan Press.

Oriyama, Kaya (2012): "What Role Can Community Contact Play in Heritage Language Literacy Development? Japanese-English Bilingual Children in Sydney". Journal of Multilingual and Multicultural Development, 33/2: 167-186.

Pauwels, Anne (2007): "Maintaining a Language Other Than English through Higher Education in Australia". In: Pauwels, Anne et al. (eds.): Maintaining Minority Languages in Transnational Contexts. Basingstoke etc.: MacMillan: 107-1123.

Pauwels, Anne (2016): Language Maintenance and Shift. Cambridge: Cambridge University Press.

Penny, H. Glenn (2012): "German Polycentrism and the Writing of History". 30: 265-282. doi:10.1093/gerhis/ghs023.

Polinsky, Maria (2018): Heritage Languages and their Speakers. Cambridge, UK: Cambridge University Press.

Polinsky, Maria (2015): "Heritage Languages and Their Speakers: State of the Field, Challenges, Perspectives for Future Work, and Methodologies". Zeitschrift für Fremdsprachenforschung, 26/1: 7-27.

Polinsky, Maria/Kagan, Olga (2007): "Heritage Languages: In the 'Wild' and in the Classroom". Language and Linguistics Compass, 1/5: 368-395.

Polinsky, Maria/Scontras, Gregory (2019): “Understanding heritage languages”. Bilingualism: Language and Cognition: 1-17. doi.org/10.1017/S1366728919000245. 
Pütz, Martin (1991): "Language Maintenance and Language Shift in the Speech Behaviour of German-Australian Migrants in Canberra”. Journal of Multilingual and Multicultural Development, 12/6: 477-492. doi:10.1080/01434632.1991.9994477.

Quay, Suzanne/Montanari, Simona (2016): "Early Bilingualism: From Differentiation to the Impact of Family Language Practices". In: Nicoladis, Elena/Montanari, Simona (eds.): $B i$ lingualism across the Lifespan: Factors Moderating Language Proficiency, American Psychological Association and de Gruyter: 23-42.

Riehl, Claudia Maria (2015): 2Language Attrition, Language Contact and the Concept of Relic Variety: The Case of Barossa German". International Journal of the Sociology of Language, 236: 261-293. doi:10.1515/ijsl-2015-0028.

Rothman, Jason (2009): "Understanding the nature and outcomes of early bilingualism: Romance languages as heritage languages”. International Journal of Bilingualism, 13/2: $155-163$.

Rubenstein, Hilary L. (1991): The Jews in Australia: A Thematic History (Vol. 1). Melbourne: Heinemann.

Rutland, Suzanne D. (1988): Edge of the Diaspora: Two Centuries of Jewish Settlement in Australia Sydney: Collins.

Salmons, Joseph C. (2005): "Community, Region, and Language Shift in German-Speaking Wisconsin". In: Hönnighausen, Lothar et al. (eds.): Regionalism in the Age of Globalism Volume 2: Forms of Regionalism. Madison, Wis., Center for the Study of Upper Midwestern Cultures: 133-144.

Schulen Auf Einen Blick (2018): www.destatis.de/DE/Themen/Gesellschaft-Umwelt/BildungForschung-Kultur/Schulen/Publikationen/Downloads-Schulen/broschuere-schulen-blick0110018189004.html.

Schulz, Peter/Soontiens, Werner (2004): Internationalisation and Country Image "Being German" in Western Australia. Perth, WA: Curtin University of Technology. School of Management.

Schüpbach, Doris (2006): “'It's Something That's Just Faded Away': How a Melbourne Family of Swiss-German Background Makes Sense of Language Shift". International Journal of the Sociology of Language, 180: 89-104. doi:10.1515/IJSL.2006.042.

Schüpbach, Doris (2009): "Language Transmission Revisited: Family Type, Linguistic Environment and Language Attitudes". International Journal of Bilingual Education and Bilingualism, 12/1: 15-30. doi:10.1080/13670050802149499.

Tampke, Jürgen/Doxford, Colin (1990): Australia, Willkommen: A History of the Germans in Australia. Kensington, N.S.W.: New South Wales University Press.

Tuominen, Anne (1999): "Who Decides the Home Language? A Look at Multilingual Families". International Journal of the Sociology of Language, 140/1: 59-76. doi:10.1515/ijsl.1999.140.59.

Van Deusen-Scholl, Nelleke (2003): “Toward a Definition of Heritage Language: Sociopolitical and Pedagogical Considerations". Journal of Language, Identity \& Education 2/3: 211-230.

Von Heinz, Kretzenbacher (2006): „Deutsche Sprache und Germanistik in Australien - Ein Paar Vorsichtig-Subjektive Perspektiven“. Jahrbuch für Internationale Germanistik, 2006/2: 11-33. doi:10.3726/82025_11. 
Vondra, Josef (1981): German Speaking Settlers in Australia. Melbourne: Cavalier Press.

Waas, Margit (1996): Language Attrition Downunder: German Speakers in Australia. Frankfurt am Main: Lang.

Wiemann, Ursula (1965): German and Austrian Refugees in Melbourne 1933-1947: A Study of their Migration, Reception and Integration into the Melbourne Community. (Masters Research thesis, Arts), The University of Melbourne. http://hdl.handle.net/11343/35933.

Wiley, Terrence G. (2005): "Commentary: Discontinuities in Heritage and Community Language Education: Challenges for Educational Language Policies”. International Journal of Bilingual Education and Bilingualism, 8/2-3: 222-229.

Winter, Joanne/Pauwels, Anne (2007): "Language Maintenance and the Second Generation: Policies and Practices". In: Pauwels, Anne et al. (eds.): Maintaining Minority Languages in Transnational Contexts. Basingstoke etc.: MacMillan: 180-200.

Wurm, Stephen A. (2002): "Strategies for Language Maintenance and Revival". In: Bradley, David/Bradley, Maya (eds.): Language Endangerment and Language Maintenance: An Active Approach. London, Routledge: 11-23.

Yagmur, Kutlay (2011): "Does Ethnolinguistic Vitality Theory Account for the Actual Vitality of Ethnic Groups? A Critical Evaluation”. Journal of Multilingual and Multicultural Development, 32/2: 111-120. doi:10.1080/01434632.2010.541914.

Zhang, Donghui (2010): "Language Maintenance and Language Shift among Chinese Immigrant Parents and their Second-Generation Children in the U.S.”. Bilingual Research Journal, 33/1: 42-60. doi:10.1080/15235881003733258. 